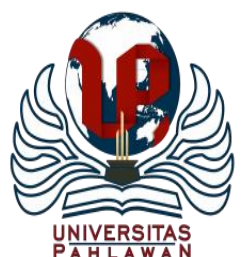

Jurnal Basicedu Volume 5 Nomor 1 Tahun 2021 Halaman 310-316

JURNAL BASICEDU

Research \& Learning in Elementary Education

https://jbasic.org/index.php/basicedu

\title{
Efektivitas Bermain Lotto untuk Meningkatkan Konsentrasi Belajar bagi Anak ADHD
}

\author{
Lola Monika Sari ${ }^{1}$, Marlina Marlina ${ }^{2}$ \\ Pendidikan Luar Biasa, Fakultas Ilmu Pendidikan, Universitas Negeri Padang, Indonesia ${ }^{1,2}$ \\ E-mail: $\underline{\text { lolamonikasari98@ gmail.com }}{ }^{1} \underline{\text { lina_muluk@ fip.unp.ac.id }}{ }^{2}$
}

\begin{abstract}
Abstrak
Penelitian ini dilatarbelakangi dengan mendapatkan seorang anak ADHD yang mengalami kesulitan konsentrasi belajar, konsentrasi belajar dalam memusatkan perhatian terhadap materi yang sedang dikerjakan. Penelitian ini bertujuan untuk meningkatkan konsentrasi belajar bagi anak ADHD di SDN 11 Pauh Padang. Jenis penelitian ini eksperimen dalam bentuk subjek tunggal (Single Subject Research) dengan desain A-B-A, subjek penelitian ini seorang anak ADHD, menunjukkan gejala kurangnya kemampuan memusatkan perhatian penuh terhadap objek. Teknik pengumpulan data dalam penelitian ini menggunakan durasi untuk melihat berapa lama anak mampu memusatkan perhatian terhadap materi yang sedang dikerjakan dalam waktu 20 menit proses pembelajaran berlangsung. Teknik analisis data menggunakan teknik visual grafik. Hasil penelitian ini menunjukkan bahwa bermain lotto dapat meningkatkan konsentrasi belajar bagi anak ADHD di SDN 11 Pauh Padang dilihat dari hasil analisis data dalam kondisi dan antar kondisi.
\end{abstract}

Kata kunci: bermain lotto, konsentrasi belajar, ADHD

\section{Abstract}

This research is based on getting an ADHD child who has difficulty learning concentration, learning concentration in focusing on the material being worked on. This study aims to increase learning concentration for ADHD children at SDN 11 Pauh Padang. This type of research experiments in the form of a single subject (Single Subject Research) with de s ain ABA, the research subject is a child with ADHD, show symptoms of a lack of ability to concentrate full attention to the object. Data collection techniques in this study used a duration to see how long the child was able to focus on the material being worked on within 20 minutes of the learning process. Data analysis techniques using visual graph techniques. The results of this study indicate that playing lotto can increase learning concentration for ADHD children at SDN 11 Pauh Padang seen from the results of data analysis in conditions and between conditions.

Keywords: playing lotto, learning concentration, $A D H D$

Copyright (c) 2021 Lola Monika Sari, Marlina Marlina

$\triangle$ Corresponding author

Address : Jln. Imam Bonjol

ISSN 2580-3735 (Media Cetak)

Email : lolamonikasari98@gmail.com

ISSN 2580-1147 (Media Online)

DOI: https://doi.org/10.31004/basicedu.v5i1.665 
311 Efektivitas Bermain Lotto untuk Meningkatkan Konsentrasi Belajar bagi Anak ADHD - Lola Monika Sari, Marlina Marlina

DOI: https://doi.org/10.31004/basicedu.v5i1.665

\section{PENDAHULUAN}

Pendidikan sangat diperlukan bagi setiap orang sebagai modal kehidupan. Keberhasilan dalam pendidikan dapat dilihat dari tercapainya tujuan pendidikan. Indikator keberhasilan tujuan pendidikan dapat dilihat dari proses pembelajaran, yang mana salah satu aspek yang mempengaruhi dalam proses pencapaian tujuan pembelajaran yaitu konsentrasi. Anak yang memiliki konsentrasi yang baik dalam belajar maka akan berpengaruh terhadap pembelajaran.

Konsentrasi dalam belajar sangat penting ketika pembelajaran berlangsung, anak yang dikatakan berkonsentrasi dalam belajar seperti anak mampu memperhatikan guru ketika sedang menjelaskan, menyimak, bertanya ketika belajar, merespon, memahami materi, menjawab soal-soal dengan benar, menginformasi kembali pengetahuan yang didapat kepada orang lain (Hasanah, Fatmawati, \& Marlina, 2018) Kurangnya konsentrasi dalam belajar ini akan mempengaruhi rendahnya prestasi belajar (Asna, 2019).

Konsentrasi merupakan pemusatan perhatian dalam sebuah kegiatan, salah satu kunci utama dalam mencapai keberhasilan tujuan kegiatan (Setyani \& Ismah, 2018). Sedangkan Menurut (Pratisti \& Yuwono, 2018) menyatakan bahwa konsentrasi merupakan kemampuan seseorang dalam memusatkan perhatian dalam jangka waktu lama untuk menyelesaikan tugasnya tanpa terganggu oleh faktor lain.

Anak yang mengalami kesulitan memusatkan perhatian biasanya terjadi pada anak ADHD dengan istilah Attention Deficit
Hyperactive Disorder. Anak ADHD menunjukkan gejala seperti memiliki gangguan pemusatan perhatian, menunjukkan perilaku seperti bergerak berlebihan atau hiperaktif, dan sulit mengendalikan diri (Marlina \& Grahita, 2019). Anak ADHD ini memiliki perilaku yang berkembang secara tidak matang atau sempurna, yang tidak sesuai pada anak umunya biasanya terjadi pada anak-anak dan orang dewasa. Perilaku yang tampak seperti kurang mampu menaruh perhatian, pengontrol gerak hati serta pengendalian motor (Marlina, 2008).

Permasalahan anak ADHD yang tampak seperti menunjukkan perilaku tidak dapat menaruh perhatian lama ketika belajar, keluar masuk kelas, dan tidak mampu menjawab dengan benar dari pertanyaan guru ketika sedang belajar, tidak fokus dalam belajar, anak tidak berkonsentrasi ketika belajar. Karena dia sering menganggu temantemannya di kelas, melamun atau tidak memperhatikan guru ketika guru menjelaskan.

Berdasarkan hasil asesmen konsentrasi belajar anak, yang terlihat bahwa anak kurang mampu menaruh perhatian dengan rentang waktu yang lama, anak hanya mampu memusatkan perhatiannya terhadap objek kurang lebih 5 menit ketika belajar, anak kurang respon terhadap pembelajaran berlangsung. Pandangan anak mudah teralihkan ketika sedang belajar, anak sering keluar masuk kelas, mengganggu temannya ketika sedang belajar, anak terlihat malas atau kurang minat ketika sedang belajar, anak kurang mampu memahami sebuah materi yang disampaikan guru ketika belajar, anak tidak mengemukakan pendapat ketika pembelajaran berlangsung atau tidak aktif 


\section{Efektivitas Bermain Lotto untuk Meningkatkan Konsentrasi Belajar bagi Anak ADHD - Lola Monika}

Sari, Marlina Marlina

DOI: https://doi.org/10.31004/basicedu.v5i1.665

dalam belajar, anak kurang mampu mengikuti perintah yang sesuai instruksi diberikan. Anak ADHD yang terlihat gejalanya seperti mengalami kesulitan dalam memusatkan perhatian, mengendalikan diri, dan gerak berlebihan atau hiperaktif (Marlina, 2015).

Jika dibiarkan saja maka akan berpengaruh terhadap prestasi belajar anak pada akademiknya. Sebelumnya yang terlihat pada proses pembelajaran berlangsung cara guru melatih kemampuan konsentrasi anak yaitu dengan media mozaik, kelemahan yang terlihat dari media mozaik ialah kurang dapat menarik minat anak ketika mengerjakannya. Adapun banyak cara dilakukan penelitian sebelumnnya untuk meningkatkan konsentrasi belajar,salah satunya penelitian yang dilakukan oleh (Yogawati, 2017) mengenai lotto dimana hasil penelitian tersebut dikatakan bahwa adanya pengaruh bermain lotto tebak suara meningkatan konsentrasi belajar anak autis di Sekolah Luar Biasa.

Lotto bisa disebut permainan edukasi, permainan yang bisa dibongkar pasang, yang berisikan warna dan berbagai macam bentuk (Dewi, Kristiantari, \& Suara, 2015). Kelebihannya dalam bermain lotto yaitu menggunakan alat indra pengelihatan dan pendengaran ketika bermain, dimana anak harus berkonsentrasi dan mempersepsikan gambar suara atau bunyi yang didengarkan ketika mencari gambar (Yogawati, 2017). Kelebihan dari lotto menurut (Sofiah, Kustiono, \& Awalya, 2019) menjelskan bahwa kelebihan pada lotto ini dengan bermain lotto yang secara bersamaan atau kooperatif, mampu meningkatkan sosial emosional anak ketika bermain.

Kekurangan pada lotto bahwa lotto ini berisikan gambar-gambar, hanya dapat dilihat saja melainkan media tidak konkrit (Nonik, Raga, \& Murda, 2013). Menurut (Emayani, Suara, \& Ardana, 2016) menjelaskan bahwa bermain lotto ini dimulai mencampur adukan semua kartu lotto kemudian menyusun lotto. Pada penelitian tersebut, penulis tertarik dengan bermain lotto untuk meningkatkan konsentrasi belajar bagi anak ADHD

\section{METODE}

Jenis penelitian ini eksperimen yang berbentuk Single Subject Research penelitian ini menggunakan desain A-B-A. Single Subject Research ini merupakan penelitian yang menganalisis tentang perilaku atau penelitian dalam subjek yang melibatkan penelitian individu tunggal ketika dari awal periode hingga memberikan intervensi (Payadnya \& Jayantika, 2018). Variabel terikat dalam penelitian ini adalah konsentrasi belajar. Konsentrasi belajar yang dimaksud berapa lama konsentrasi belajar anak dalam memusatkan perhatiannya terhadap materi selama 20 menit. Pada variabel bebasnya yaitu bermain lotto. Menurut (Putri, Pudjawan, Ujianti, \& Psi, 2016) lotto merupakan media yang membantu mengembangkan kognitif anak dari segi bentuk dan warna. Lotto merupakan media yang berbentuk kartu gambar dengan berbagai macam gambar, langkah-langkah dalam bermain lotto hewan dimulai dari menghidupkan suara-suara 
313 Efektivitas Bermain Lotto untuk Meningkatkan Konsentrasi Belajar bagi Anak ADHD - Lola Monika Sari, Marlina Marlina

DOI: https://doi.org/10.31004/basicedu.v5i1.665

hewan, kemudian mencari gambar sesuai suara didengar kemudian ditempelkan ke papan lotto.

Subjek penelitian adalah anak ADHD yang mengalami kesulitan dalam memusatkan perhatian berinisial $\mathrm{F}$ berjenis kelamin laki-laki, umur 11 tahun, kelas IV di SDN 11 Pauh Padang.Teknik pengumpulan data yang digunakan dengan cara observasi langsung yaitu melalui tes, wawancara, obeservasi, dan dokumentasi. Jenis tes yang digunakan yaitu tes perbuatan berfungsi untuk melihat kemampuan konsentrasi belajar anak yaitu berapa lama anak mampu memusatkan perhatian penuh terhadap materi yang sedang dikerjakan ketika prembelajaran berlangsung selama 20 menit, diukur menggunakan durasi dengan menggunakan stopwatch.

\section{HASIL DAN PEMBAHASAN}

Penelitian ini dilakukan sebanyak 18 kali pertemuan dimana kondisi baseline (A1) dilakukan sebanyak tujuh kali pertemuan, kondisi intervensi (B) dilakukan sebanyak tujuh kali pertemuan, dan kondisi baseline kedua (A2) dilakukan sebanya kenam kali pertemuan. Berikut ini hasil data perbandingan antara kondisi baseline (A1), intervensi (B), dan baseline (A2).

Berdasarkan grafik 1, diketahui bahwa kemampuan konsentrasi belajar anak ADHD, kondisi baseline (A1) pada hari pertama konsentrasi 2 menit, pada hari kedua 3 menit, pada hari ketiga 1 menit, hari 1 menit, dan hari kelima 1 menit. Pada kondisi A1 ini mean levelnya adalah 1,6, batas pada kondisi (A1) ini adalah 1,82 sedangkan batas bawahnya 1,37 , persentasenya adalah $0 \%$.

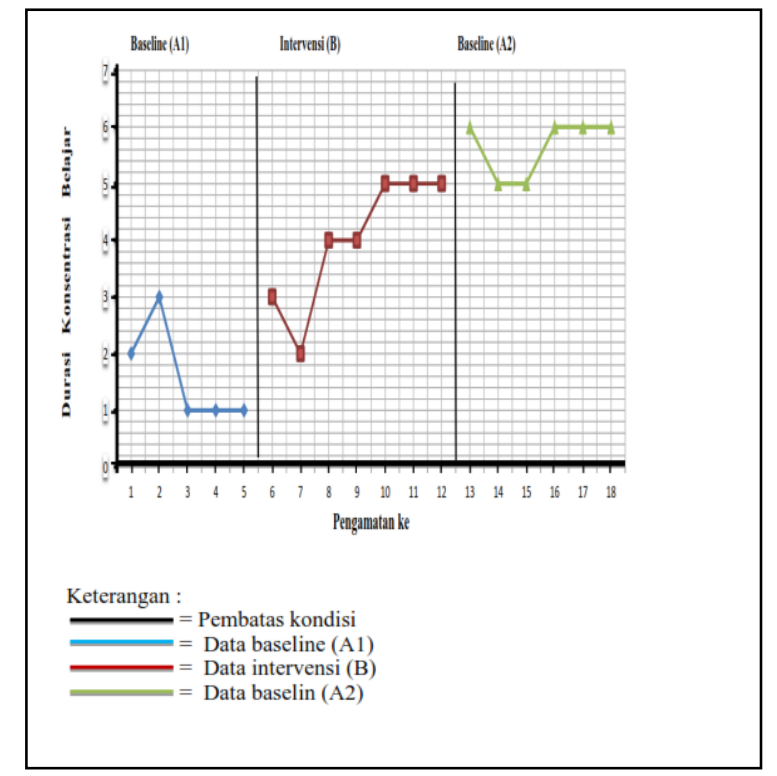

Grafik. 1 Analisis dalam Kondisi Data Konsentrasi Belajar

Selanjutnya dilakukan intervensi (B) setelah data pada baseline (A1) sudah stabil. Intervensi yang diberikan yaitu bermain lotto. Cara bermain lotto dalam penelitian ini yaitu lotto bisa dimainkan dengan 2-3 orang anak, Pertama keseluruhan lotto gambar hewan disusun acak dengan posisi terbalik, anak diperdengarkan suara hewan dan anak mencari lotto gambar hewan sesuai suara yang diperdengarkan. Setelah anak menemukan lotto gambar hewan, anak diminta menempelkan lotto gambar hewan kepapan lotto. Dalam satu kali permainan ada 5 buah suara hewan yang diperdengarkan, tiap- tiap pertemuan suara hewan yang dibunyikan berbeda-beda.

Intervensi ini dilakukan dengan panjang kondisi tujuh kali pertemuan dengan mean level 4. Pengamatan pada kondisi intervensi ini dilakukan pada keenam sampai kedua belas setelah diberikan intervensi bermain lotto. Pada hari keenam konsentrasi belajar anak yaitu 3 menit, hari ketujuh 2 menit, hari kedelapan 4 menit, hari kesembilan 4 
314 Efektivitas Bermain Lotto untuk Meningkatkan Konsentrasi Belajar bagi Anak ADHD - Lola Monika Sari, Marlina Marlina

DOI: https://doi.org/10.31004/basicedu.v5i1.665

menit, hari kesepuluh 5 meint, hari kesebelas 5 menit, dan hari kedua belas 5 menit. Batas atas pada kondisi intervensi ini yaitu 4,37 dan batas bawahnya yaitu 3,62. Persentasenya stabilitas pada kondisi intervensi yaitu 42\%. Dengan diberikan perlakuan estimasi kecendrungan arah pada kondisi ini meningkat.

Saat data intervensi stabil maka dilanjutkan pada kondisi baseline kedua (A2). Panjang kondisi pada baseline kedua ini (A2) yaitu enam kali pertemuan dimulai dari pertemuan ketiga belas sampai kedelapan belas. Pada hari ketiga belas konsentrasi belajar yaitu 6 menit, hari keempat belas 5 menit, hari kelima belas 5 menit, keenam belas 6 menit, ketujuh belas 6 menit, kedelapanbelas 6 menit, Dengan mean level 5,6 batas atasnya yaitu 6,05 , batas bawah 5,15 . Persentasenya $100 \%$, persentase kecenderungan stabilitas arah pada baseline kedua ini mengalami peningkatan. Data kemudian dianalisis melalui analisis antar kondisi dalam meningkatan konsentrasi belajar anak ADHD dengan melalui bermain lotto.

Analisis Antar kondisi yaitu jumlah variabel yang berubah adalah satu dengan target behaviour yaitu konsentrasi belajar. Pada perubahan kecenderungan arah yaitu dengan mengambil data analisis dalam kondisi. Kecendrungan arah konsentrasi belajar pada kondisi baseline A1 (-), untuk kecenderungan arah B (+), sedangkan arah pada kondisi baseline A2(+). Oleh sebab itu dapat diketahui bahwa pemberian intervensi berpengaruh yang positif pada variabel yang diubah. pada level perubahan pada ketiga kondisi tersebut, dengan melihat data poin terakhir dikurangi dengan data poin pertama. Pada kondisi baseline (A1) data poin pertama2 dan data terakhir adalah 1 maka 2-1 = -1 (-). Pada kondisi intervensi (B) data pertama 3 dan data terakhir 5 jadi 5-3=2. hal ini menunjukkan level perubahanya (+) positif atau meningkat. Sedangkan pada kondisi baseline (A2) data pertama 6 dan data terakhir 6 , jadi $6-6=0(=)$. Maka level perubahannya tidak ada perubahan atau mendatar. Sedangkan presentase overlap konsentrasi belajar pada kondisi baseline (B) terhadap kondisi (A1) menunjukkan 0\% dan kondisi intervensi (B) terhadap kondisi (A2) $0 \%$. Semakin kecil persentase yang terdapat pada kondisi overlape maka semakin baik pengaruh intervensi terhadap perubahan target behaviour dalam suatu penelitian.

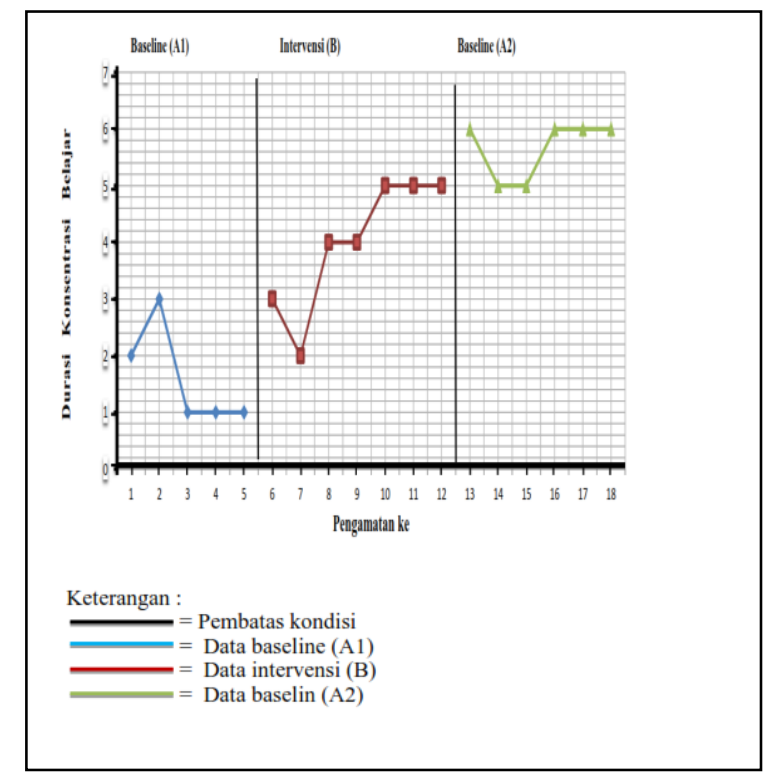

Grafik 2. Analisi Antar Kondisi Data Konsentrasi Belajar

Penelitian ini membahas tentang efektivitas bermain lotto untuk meningkatkan konsentrasi belajar bagi anak ADHD kelas VI di SDN 11 Pauh 
315 Efektivitas Bermain Lotto untuk Meningkatkan Konsentrasi Belajar bagi Anak ADHD - Lola Monika Sari, Marlina Marlina

DOI: https://doi.org/10.31004/basicedu.v5i1.665

Padang. Berdasarkan hasil penelitian yang telah dilakukan kepada salah satu anak, yang masalah anak yang memiliki kemampuan pemusatan perhatian jangka waktu pendek ketika belajar, dimana anak kesulitan memusatkan perhatian terhadap objek dengan jangka waktu lama.

Hasil penelitian ini menunjukkan bahwa bermain lotto dapat meningkatkan konsentrasi belajar anak ADHD sesuai data yang telah dianalisis. Hasil penelitian ini menunjukkan bahwa bermain lotto dapat meningkatkan konsentrasi belajar anak ADHD sesuai data yang telah dianalisis. Langkah dalam bermain lotto hewan yaitu pertama lotto gambar hewan disusun secara acak dan terbalik, lalu anak diminta mendengarkan suara hewan yang ada dispeaker. Kemudian anak diminta mencari lotto gambar hewan sesuai suara yang didengar, setelah menemukan lotto gambar hewan anak diminta menempelkan lotto gambar hewan kepapan lotto. bermain lotto ini tidak hanya melatih konsentrasi anak ketika bermain tetapi bisa memperoleh rasa senang dan dapat berpikir kritis saat memecahkan masalah (Laris, Wayan, \& Tirtayani, 2014).

Pada bermain lotto ini dapat melatih fokus anak ketika mendengarkan suara sampai memperhatikan gambar sesuai dengan suara tersebut. Karena dalam bermain lotto ini menggunakan alat indra pengelihatan dan pendengaran ketika bermain, dimana anak harus berkonsentrasi dan mempersepsikan gambar suara atau bunyi yang didengarkan ketika mencari gambar (Yogawati, 2017).

Begitupun dengan hasil penelitian yang dilakukan (Yogawati, 2017) menjelaskan bahwa dengan bermain lotto (tebak suara) terhadap konsentrasi belajar anak autis di Sekolah Luar Biasa menyatakan hasil penelitianya yaitu ada pengaruh lotto terhadap konsentrasi belajar anak autis. Berdasarkan paparan diatas, jika bermain lotto dapat dilaksanakan maka akan membantu meningkatkan kemampuan konsentrasi beajar anak ADHD.

\section{SIMPULAN}

Bermain lotto ini menggunakan alat indera pendengaran dan pengelihatan ketika sedang bermain sehingga anak fokus dalam bermain, dari analisis data secara keseluruhan pada analisis data dalam kondisi dan analisis data antar kondisi menunjukkan adanya peningkatan konsentrasi belajar bagi anak ADHD. Hasil perolehan data maka bermain lotto berpengaruh sehingga dapat meningkatkan konsentrasi belajar anak ADHD di SDN 11 Pauh Padang.

\section{DAFTAR PUSTAKA}

Asna, A. (2019). Peningkatan Konsentrasi Siswa dengan Metode Picture to Picture Pada Pembelajaran Pendidikan Pancasila Kewarganegaraan di Kelas VII3 SMP Negeri 7 Muara Bungo. Jurnal Muara Pendidikan, 4(1), 268-275.

Dewi, A. A. G. I., Kristiantari, R., \& Suara, M. I. (2015). Penerapan Model Pembelajaran Think Pair Sharae Berbantuan Media lotto Warna dan Bentuk untuk Meningkatkan Perkembangan Kognitif Anak Kelompok B3. E-Journal PG-Paud Universitas Pendidikan Ganesha, 3(1).

Emayani, W. N., Suara, M. I., \& Ardana, K. I. (2016). Penerapan Metode Bermain Berbantuan Media Lotto untuk Meningkatkan Kemampuan Kognitif Pada 
316 Efektivitas Bermain Lotto untuk Meningkatkan Konsentrasi Belajar bagi Anak ADHD - Lola Monika Sari, Marlina Marlina

DOI: https://doi.org/10.31004/basicedu.v5i1.665

Anak Kelompok. Jurnal Pendidikan Anak Usia Dini Undiksha B1, 4(1).

Hasanah, H. W., Fatmawati, F., \& Marlina, M. (2018). Peningkatan Ketahanan Duduk dan Pengurangan Perilaku Meninggalkan Tempat Duduk Melalui Teknik Time Out Pada Anak Attention Deficit Hyperactivity Disorder. Jurnal Pendidikan Kebutuhan Khusus, 2(1), 26-31.

Laris, P. N., Wayan, S. I., \& Tirtayani, A. L. (2014). Pemanfaatan Media Lotto untuk Meningkatkan Perkembangan Kognitif Anak Kelompok A di Paud Santi Kumara. Jurnal Pendidikan Pendidikan Anak Usia Dini, 2(1).

Marlina. (2008). Gangguan Pemusatan Perhatian dan Hiperaktivitas Pada Anak. Padang: UNP Press.

Marlina. (2015). Asesmen Anak Berkebutuhan Khusus (Pendekatan Psikoedukasional.) Padang: UNP Press.

Marlina, \& Grahita, K. (2019). Strategi Penanganan Anak ADHD. Jakarta: Prenadamedia Group.

Nonik, N. N., Raga, I. G., \& Murda, I. N. (2013). Penerapan Metode Demonstrasi dengan Media Kartu Gambar untuk Meningkatkan Kemampuan Kognitif Anak Kelompok A di Paud Widya Dharma Bondalem Tejakula. Jurnal Pendidikan Anak Usia Dini Undiksha, 1(1).

Payadnya, Andre Ade Putu I., \& Jayantika, Trisna Ngurah Agung Gusti I. (2018). Panduan Penelitian Eksperimen Beserta Analisis Statistik dengan SPSS. Yogyakarta: CV Budi Utama.

Pratisti, D. W., \& Yuwono, S. (2018). Psikologi Eksperimen: Konsep, Teori, dan Aplikasi. Sukarta: Muhammadiyah University Press.

Putri, N. L. S. L., Pudjawan, K., Ujianti, P. R., \& Psi, S. (2016). Penerapan Metode Bermain Berbantuan Media Lotto untuk Meningkatkan Perkembangan Kognitif. Jurnal Pendidikan Anak Usia Dini Undiksha, 4(2).

Setyani, M. R., \& Ismah, I. (2018). Analisis
Tingkat Konsentrasi Belajar Siswa dalam Proses Pembelajaran Matematika ditinjau dari Hasil Belajar. Prosiding Senamku, 1, 73-84.

Sofiah, S., Kustiono, K., \& Awalya, A. (2019). Development of Cooperative Learning Model Assisted by Lotto Educative Media to Improve Emotional Social Early Childhood. Journal of Primary Education, 39-47.

Yogawati, R. H. (2017). Bermain Lotto (Tebak Suara) Terhadap Konsentrasi Belajar Anak Autis di Sekolah Dasar Luar Biasa. Jurnal Pendidikan Khusus, 9(4). 